Наталя Колотова,

Воєнно-дипломатична академія імені Свгенія Березняка

ORCID ID 0000-0003-2188-4530

\title{
РОЗВИТОК ПРОФЕСІЙНОЇ ГОТОВНОСТІ ДО МІЖКУЛЬТУРНОЇ ВЗАСМОДІЇ МАЙБУТНІХ МАГІСТРІВ ВІЙСЬКОВОГО УПРАВЛІННЯ В МІЖНАРОДНИХ ВІДНОСИНАХ ЯК ПРЕДМЕТ НАУКОВО-ПЕДАГОГІЧНОГО АНАЛІЗУ
}

У статті розглянуто проблему розвитку професійної готовності до міжкультурної взаємодії у системі професійної підготовки майбутніх магістрів військового управління в міжнародних відносинах. Проаналізовано розвиток професійної готовності майбутніх воєнних дипломатів до міжкультурної взаємодії як педагогічний процес, визначено сутність иьього поняття у системі поглядів сучасної педагогічної науки. Як ключовий компонент забезпечення результативності й ефективності міжкультурної взаємодії, визначено лінгвосоціокультурну компетентність. Доведено, щуо розвиток професійної готовності до міжкультурної взаємодії сприятиме удосконаленню професійної підготовки майбутніх воєнних дипломатів.

Ключові слова: міжкультурна взаємодія; магістри військового управління в міжнародних відносинах; професійна підготовка; професійна готовність до міжкультурної взаємодї; воєнно-дипломатична служба.

Постановка проблеми. Діяльність держав, міжнародних організацій, інших впливових міжнародних акторів, метою якої $\epsilon$ вплив на іноземну громадськість, визначають як громадську або публічну дипломатію. Цей тренд зовнішньої політики держави останнім часом набуває все більшої важливості. Здійснення публічної дипломатії є можливим лише за умови успішної міжкультурної взаємодії, яку у воєнній сфері здійснюють воєнні дипломати - магістри військового управління у міжнародних відносинах. До їх функціональних обов'язків належить просування національних інтересів та створення позитивного міжнародного іміджу нашої країни. Такі фахівці мають бути готовими до проведення відповідної інформаційної діяльності та впливу на зовнішню аудиторію. Розвиток професійної готовності до міжкультурної взаємодії майбутніх фахівців воєнно-дипломатичної служби лежить у площині багатьох фахових дисциплін, які викладаються у Воєннодипломатичній академії імені Свгенія Березняка - закладі вищої освіти (ЗВО) воєнно-дипломатичної служби. Проте, існує необхідність з' ясування ступеню дослідження цієї проблеми у сучасній педагогічній науці.

Аналіз останніх досліджень і публікацій. Проблемні питання формування і розвитку професійної готовності до різних видів діяльності частково досліджувалася у працях багатьох науковців Б. Ананьєва, С. Рубінштейна, Д. Узнадзе, Г. Гагаєвої, С. Ільїна, С. Ніколаєнко, П. Рябцева, Ю. Самаріна, М. Томчука, О. Ухтомського, О. Юдіної та ін., проте комплексний аналіз наукової літератури з проблем розвитку професійної готовності до міжкультурної взаємодії майбутніх воєнних дипломатів, який би враховував специфіку їх фахової діяльності, здійснено не було. 
Мета статті. Визначити сутність поняття "професійна готовність майбутніх воєнних дипломатів до міжкультурної взаємодіі” у системі поглядів сучасної педагогічної науки.

Методи дослідження. Аналіз теоретичних джерел із проблеми професійної підготовки військових фахівців, теорії та методики формування готовності майбутніх офіцерів до професійної діяльності; класифікація та систематизація теоретичних даних; конкретизація теоретичного та практичного знання; порівняльний аналіз отриманих теоретичних матеріалів щодо теорії розвитку готовності майбутніх воєнних фахівців до професійної діяльності та її впровадження у професійну підготовку воєнних дипломатів у 3BO.

Виклад основного матеріалу. Аналіз наукової літератури показав різноманітні бачення проблеми професійної готовності до фахової діяльності. Так, теоретико-методологічні основи наукового розв'язання загальнопедагогічних проблем розвитку готовності до професійної діяльності висвітлено в працях Б. Ананьєва, С. Рубінштейна, Д. Узнадзе. У їхніх роботах готовність до фахової діяльності висвітлюється як особливий психічний стан, що займає проміжне положення між психологічними процесами та якостями особистості, тобто на функціональному рівні.

Цікавими для нашого дослідження $є$ роботи Г. Гагаєвої, Є. Ільїна, С. Ніколаєнко, П. Рябцева, Ю. Самаріна, М. Томчука, О. Ухтомського, О. Юдіної, які визначали готовність до фахової діяльності як психічний стан особистості, що проявляється в активно-позитивному ставленні до фаху i зумовлює формування такого стану змобілізованості психіки, що забезпечує здатність приймати самостійні рішення при виникненні складних професійних завдань та оцінювати свої можливості у співвідношенні до майбутніх труднощів.
С. Кучеренко,
В. Петренко,
В. Синявський,
А. Тарновська інтерпретують готовність до фахової діяльності як цілеспрямований вияв особистості, яка охоплює систему професійних знань, навичок та умінь, потреб, мотивів, психологічних якостей і психічних процесів, що забезпечує успішне виконання професійної діяльності на оптимальному рівні.

Для нашого дослідження особливо цінними є розвідки М. Д'яченка та Л. Кандибовича щодо розгляду готовності як системи зі складною динамічною структурою, яка містить в собі такі компоненти:

мотиваційний, що включає позитивне ставлення до професії, почуття обов'язку, відповідальність за виконання завдань;

орієнтаційний, де розглядаються знання й уявлення про особливості та умови діяльності, ऑї вимоги стосовно особистості;

операційний, а саме: оволодіння способами і прийомами діяльності, необхідними знаннями, вміннями, навичками, процесами аналізу, синтезу, порівняння, узагальнення тощо;

вольовий, тобто самомобілізація, самоконтроль, уміння управляти діями, з яких складається виконання обов'язків; 
оцінювальний, де основна увага зосереджена на самооцінці своєї підготовленості щодо оптимального вирішення професійних завдань [2, с. 93].

Зокрема, В. Фофанов довів, що первинною $є$ не діяльність одного 3 суб'єктів, а їх взаємодія, яка постає як основа для спільної діяльності, оскільки людина відчуває потребу в іншій людині як співучасника свого буття. Тільки в тому випадку, коли кожен учасник взаємодії задовольняє свої професійні потреби, мотиви, цілі й створює умови для самореалізації партнера зі спілкування, фахову міжкультурну взаємодію можна вважати ефективною [5, с. 196-197].

За нашим досвідом, особливістю професійної підготовки майбутніх воєнних дипломатів $\epsilon$ те, що у цих фахівців потрібно розвивати готовність приймати рішення, брати на себе відповідальність за ці рішення, здійснювати професійну діяльність іноземною мовою 3 урахуванням контекстуальної значущості ситуації, особливостей мовної картини світу країни перебування, лінгвістичних i екстралінгвістичних чинників, що обумовлюють ведення фахової міжкультурної взаємодії.

О. В. Бойко довів, що те, що звичайно називається установкою й факторами готовності до дії - це особливий функціональний стан клітин кори мозку, який виражається у вибірковому тонічному підвищенні збудливості цих клітин під впливом мовного подразника, тому вважаємо, що професійна готовність майбутніх воєнних дипломатів до міжкультурної взаємодії залежить, в першу чергу, від володіння мовою [1, с. 132].

На особливу увагу заслуговує розповсюдженість вживання саме англійської мови як мови спілкування в дипломатичному середовищі. 3 одного боку, в більшості випадків така міжкультурна взаємодія відбувається між іноземцями - представниками різних культур, які використовують англійську мову - іноземну для всіх або більшості учасників спілкування (за виключенням випадків, коли хтось із учасників є носієм англійської). Це створює підгрунтя для більшої толерантності, щонайменше для усвідомлення можливих культурних розбіжностей, адже всі учасники такої взаємодії докладають певних зусиль для передачі своїх думок засобами іноземної мови. 3 другого боку, використання англійської мови підвищує вимоги до рівня володіння фахівцями-міжнародниками цією мовою, адже використання всіма учасниками міжкультурної взаємодії означає, що всі знаходяться в рівних умовах і факт використання нерідної мови не $є$ підставою для спрощеного сприйняття помилок, зважаючи на те, що воєнний дипломат говорить іноземною мовою.

Оскільки мовленнєва діяльність психологічно організована подібно іншим видам діяльності, тобто, з одного боку, характеризується предметним мотивом, цілеспрямованістю, а 3 другого - складається 3 орієнтування, планування, реалізації плану та контролю. Таким чином, щоразу людині необхідно вміти орієнтуватися в умовах спілкування, а саме визначати для себе місце, роль висловлювання, а також в загальних рисах його форму. 3 
урахуванням загального мотиву діяльності уточнити мету мовленнєвої дії i, відштовхуючись від умов комунікації (усне/письмове спілкування, аудиторія, офіційність ситуації та ін.), вирішити питання про форму, вид, стиль висловлювання тощо.

У дослідженні І. Ігнатової виокремлюються такі чотири рівні засвоєння мови:

пізнавальний, коли той, хто вчиться, визначає, розрізняе ті чи інші явища у порівнянні 3 іншими. Він характерний для початкового етапу процесу навчання (запам'ятовування окремих об'єктів - слів, речень тощо);

рівень репродукції, коли відтворюється інформація на рівні пам'яті і розуміння;

орієнтувально-мовний, який передбачає оволодіння уміннями застосовувати засвоєну інформацію в процесі комунікації;

трансформаційний, коли майбутній фахівець досягає досконалості в оволодінні інформацією, що виражається в умінні трансформувати знання;

варіативно-творчий, коли той, хто вчиться, здатний самостійно варіювати засвоєні моделі у різних мовних ситуаціях [3, с. 128].

Професійну готовність до фахової міжкультурної взаємодії характеризують уміння класифікувати лінгвокультурологічні явища, співвідносити їх із іншими явищами в системі мови та культури, які вивчаються і досягаються на основі свідомого засвоєння знань про мовні одиниці, їх граматичні форми, виражені в культурологічних текстах [4, с. 44].

Вважаємо, що професійна готовність майбутніх воєнних дипломатів до міжкультурної взаємодії - це складне інтегративне особистісне утворення, основу якого складають ціннісні орієнтації, потреби й мотиви діалогічної взаємодії; особистісно-професійні якості (емпатія, соціальна відповідальність); система знань, умінь і навичок конструктивної взаємодії 3 представниками інших культур, що забезпечують ефективне виконання професійних функцій у процесі міжкультурної взаємодії.

Під формуванням готовності майбутніх воєнних дипломатів до фахової міжкультурної взаємодії розуміємо педагогічний процес, у якому на основі створення цілісної системи впливу на особистість, діяльність та характер соціальної взаємодії відбувається інтелектуальний розвиток і виховання медіатора культур, виражені у поведінці і діяльності, передусім комунікативній.

Проте, вміння розрізняти ті чи інші явища, виконувати аналіз, успішно складати усні і письмові повідомлення не гарантує ефективної фахової міжкультурної взаємодії. На нашу думку, практична готовність включає лінгвосоціокультурну компетентність як ключовий компонент забезпечення результативності й ефективності міжкультурної взаємодії майбутнього воєнного дипломата.

Лінгвосоціокультурна компетентність майбутніх воєнних дипломатів це цілісна система навичок і вмінь, які дозволяють майбутнім військовим фахівцям в міжнародних відносинах використовувати лінгвокраїнознавчі та 
фонові знання про національні традиції, норми та цінності національної культури, специфіку вербальної та невербальної поведінки, яка прийнята у країні, мова якої вивчається, та розуміти відмінності між рідною й іншомовною культурами, що в сукупності дозволяє їм асоціювати з мовною одиницею ту ж саму інформацію, що й носій цієї мови, досягаючи у такий спосіб повноцінної комунікації 3 іноземцями під час виконання фахових завдань.

Виходячи 3 цього, при визначенні особливостей формування професійної готовності майбутніх воєнних дипломатів до міжкультурної взаємодії, слід звернути увагу на такі компоненти (види готовності): мотиваційна; особистісна; операціональна; перцептивно-пізнавальна; комунікативно-рефлексивна.

Мотиваційна готовність охоплює пізнавальні навчальні універсальні дії, a саме: виявлення майбутніми дипломатами потреби в спілкуванні англійською мовою, виявлення зацікавленості та прагнення до пізнання нових явищ.

Особистісна готовність включає особистісні та регулятивні навчальні універсальні дії, що вимагають усвідомлення своїх інтересів для вибудовування стратегії освіти та самоосвіти, а також значущість оволодіння англійською мовою як засобом для подальшої самоосвіти.

Операціональна готовність інкорпорує міжпредметні дії, що пов'язані 3 вмінням вилучати інформацію та аналізувати їі.

Перцептивно-пізнавальна готовність включає в себе дії по орієнтуванню в структурному та логіко-смисловому змісті повідомлення.

Комунікативно-рефлексивна готовність охоплює комунікативні дії, що передбачають рефлексію відносно обміну інформацією та ефективності кожної взаємодії.

Зважаючи на різноманітність і складність завдань, які виконують в щоденній професійній діяльності військові дипломати, трансформаційний рівень є мінімально-необхідним для участі у міжкультурній взаємодії, проте, для ефективної професійної діяльності орієнтиром має бути досягнення варіативно-творчого рівня.

Висновки та перспективи подальших досліджень. Готовність до професійної діяльності розглядається педагогами на функціональному рівні, тобто як особливий психічний стан, що займає проміжне положення між психологічними процесами та якостями особистості, зокрема як:

стан змобілізованості психіки, що забезпечує здатність виконувати фахові завдання;

сукупність професійних знань, навичок та умінь, потреб, мотивів, психологічних якостей $\mathrm{i}$ психічних процесів, що забезпечує успішне виконання професійної діяльності на оптимальному рівні;

динамічна структура, яка складається із мотиваційного, орієнтаційного, операційного, вольового та оцінювального компонентів. 
Встановлено, що специфіка професійної готовності майбутніх воєнних дипломатів передбачає здатність до іншомовної комунікації, тобто спілкування іноземною мовою. Формування такої готовності - це педагогічний процес, який передбачає розвиток i виховання особисті майбутнього фахівця як медіатора культур. Ключовим елементом готовності $\epsilon$ лінгвосоціокультурна компетентність як цілісна система навичок і вмінь, які дозволяють майбутнім військовим фахівцям в міжнародних відносинах використовувати лінгвокраїнознавчі та фонові знання для встановлення i підтримання належної фахової взаємодії з іноземцями.

Визначено, що професійна готовність до міжкультурної взаємодії майбутніх воєнних дипломатів складається із таких компонентів: мотиваційного; особистісного; операціонального; перцептивнопізнавального; комунікативно-рефлексивного, що мають стати предметом подальших досліджень.

\section{ЛІТЕРАТУРА}

1. Бойко О. В. Технологія формування психологічної готовності майбутніх магістрів військово-соціального управління до виконання функцій керівників-лідерів. Військова освіта. Київ, 2004. № 14. С. $126-135$.

2. Дьяченко М. И., Кандыбович Л. А. Психология высшей школы : учебное пособие. Минск: Изд-во БГУ, $1981.383 \mathrm{c.}$

3. Игнатова И. Б. Обучение грамматическому строю речи иностранных студентовфилологов как основа формирования языковой личности будущего учителя : дис. ... д-ра пед. наук : 13.00.02. СПб., 1997. 420 с.

4. Свойкина Л. Ф. Педагогические условия формирования межкультурной коммуникации у студентов-экономистов в процессе обучения иностранному языку : дис. канд. пед. наук : 13.00.08. Белгород, 2008. 213 с.

5. Фофанов В. П. Социальная деятельность как система: учебное пособие. Москва: Наука, 1981.240 с.

\section{REFERENCES}

1. Boiko, O. V. (2004). Tekhnologiya formuvannya psykhologychnoyi gotovnosti maibutnih magistriv viyskovo-sotsialnogo upravlinnya do vykonannya funktsiy kerivnykivlideriv [Technology of Developing Would-be Masters' of Military and Social Command and Control Psychological Readiness for Performing Leadership Functions]. Viyskova osvita. 14. 126 - 135. (in Ukrainian).

2. Diachenko, M. I., Kandybovich, L. A. (1981). Psikhologiya vysshey shkoly [Higher School Psychology]. Minsk: Isd-vo BGU (in Russian).

3. Ignatova, I. B. (1997). Obuchenie grammaticheskomu stroyu rechi inostrnnykh studentov-filologov kak osnova formirovaniya yazykovoy lichnosti buduschego uchitelya [Training Foreign Students Philologists' Grammar as a Basis for the Formation of the Personality of the Future Teacher]. Doctor of Sciences dissertation (Education). Russian State Pedagogic University named after A.I. Gertsen. SPb. (in Russian).

4. Svojkina, L. F. (2008). Pedagogicheskie usloviya formirovaniya mezhkulturnoy kommunikatsii u studentov-ekonomistov v protsesse obuchenia inostrannomu jazyku [Pedagogic Conditions of Formation Economics Students in Intercultural Communication during Foreign Language Learning]. PhD Dissertation (Education). Belgorod State University of Culture and Arts. Belgorod (in Russian).

5. Fofanov, V. P. (1981). Sotsialnaya deyatelnost' kak sistema [Social Activity as a System] Moskva : Nauka (in Russian). 


\section{РЕЗЮМЕ}

Наталья Колотова,

Военно-дипломатическая академия имени Евгения Березняка

\section{Развитие профессиональной готовности к межкультурному взаимодействию будущих магистров военного образования в международных отношениях как предмет научно-педагогического анализа}

В статье рассмотрена проблема развития профессиональной готовности $\kappa$ межкультурному взаимодействию в системе профессиональной подготовки будущих магистров военного управления в международных отношениях. Исследовано развитие профессиональной готовности будущих военных дипломатов $\kappa$ межкультурному взаимодействию как педагогический процесс, определено суть этого понятия в системе взглядов современной педагогической науки. Как ключевой компонент обеспечения результативности и эффективности профессионального межккультурного взаимодействия определено лингвосоциокультурную компетентность. Доказано, что развитие профессиональной готовности к межкультурному взаимодействию будет способствовать совершенствованию профессиональной подготовки военных дипломатов.

Ключевые слова: межкультурное взаимодействие; магистры военного управления в международных отношениях; профессиональная подготовка; профессиональная готовность $\kappa$ межкультурному взаимодействию; лингвосочиокультурная компетентность; военно-дипломатическая служба.

\section{SUMMARY}

Natalia Kolotova, Military Diplomatic Academy named after Yevheniy Berezniak

\section{Development of Professional Readiness for Intercultural Interaction of the Future Masters of Command and Control in International Relations as a Subject of Scientific Pedagogic Analysis}

Introduction. Military diplomats are involved in intercultural interaction in order to establish and keep up good relations with their counterparts from foreign countries. The essential part for their success in performance of professional tasks is their readiness for intercultural interaction. It has been under research of many scientists but the peculiarities of military diplomats' professional training are not reflected in their works.

Purpose. It is to define the professional readiness of the future military diplomats for intercultural interaction within the system of modern pedagogic views.

Methods. Analysis, induction, deduction, classification, systematization and comparative analysis of theoretical sources on the problem of professional training of the would-be military diplomats.

Results. It has been found out that peculiarities of the would-be military diplomats' professional readiness for intercultural interaction include a capability of foreign language communication. The development of such readiness is a learning process encompassing development and upbringing of a specialist as a mediator of cultures. The key element of such readiness is lingvo-socio-cultural competence as an integral system of skills allowing for the future military specialists in international relations to apply country-studies and background knowledge for establishing and keeping up professional interaction with foreigners.

It also has been defined that the future military diplomats' professional readiness for intercultural interaction consists of such components as motivational, personal, operational, perceptional and cognitional, communicative and reflexive. 
Originality. A new idea of the would-be military diplomats' professional readiness for intercultural interaction with a lingvo-socio-cultural competence as its key element has been introduced. It includes a system of interrelated components the development of which increases efficiency of the future Masters of Command and Control in International Relations capability of performing professional tasks.

Conclusion. Based on the analysis of contemporary pedagogical sources the future military diplomats' professional readiness for intercultural interaction is defined as their ability to communicate with foreigners on professional topics.

Key words: intercultural communication; Masters of Command and Control in International Relations; professional training; professional readiness for intercultural communication; lingvo-socio-cultural competence; military diplomatic service. 